\title{
繰り返し荷重を受ける鋼部材と鋼材の損傷の関係 RELATIONSHIPS OF DAMAGE BETWEEN STEEL MEMBER AND MATERIAL SUBJECTED TO CYCLIC LOADING
}

\author{
山田哲*1, 鄭 景 洙*2, 吉 敷 祥一*3 \\ Satoshi YAMADA, Kyung-Soo CHUNG and Shoichi KISHIKI
}

\begin{abstract}
Seismic performance of steel structure is based on the energy absorption capacity of structural members. Energy absorption capacity of steel member is determined by cumulative plastic strain. Therefore, it is important to evaluate how the steel member and material are related respectively on the plastic deformation capacity. In this study, the numerical analysis on beams and beam-columns was carried out. The analytical parameters were the lengths of members, material properties, axial force ratios, and cyclic loading types. The stress-strain relationship on the node of member was evaluated by plastic deformation capacity, accompanied with hysteretic behavior of member. The results showed that the reasonable relation between material and member on plastic deformation capacity under hysteretic behavior could be explained by the energy absorption capacity.
\end{abstract}

Keywords: Steel Beam Column, Load Deformation Relationship, Stress Strain Relationship

Energy Absorption Capacity, Skeleton Curve, Baushinger Effect

鋼部材, 荷重-変形関係, 応力度-歪度関係, エネルギ一吸収能力, 骨格曲線, バウシンガー効果

\section{1. 序}

エネルギーの釣り合いに基づく耐震設計 ${ }^{11,2)}$ では、地震の荷重効 果をエネルギー入力として捉え、構造物の耐震性能を構成部材の塑 性変形能力に基づき評価されるエネルギー吸収能力として招える。 部材の塑性変形能力は塑性化する部位に生じる歪量に支配されるこ とから、骨組、部材、素材の損傷を関連付け、これらを総合的に評 価することは重要な課題である。素材のエネルギ一吸収能力を十分 に活かした耐震部材を骨組内に適切に配置した設計ができれば、効 果的な耐震性能の確保・向上が期待できる。

エネルギーの釣り合いに基づく耐震設計では、部材の塑性変形能 力の評価尺度して累積塑性変形倍率 $\eta$ 用いられる。これは图-1に 示すような完全弾塑性型の復元力特性を仮定した場合、各半サイク ル毎の塑性変形量 $\theta_{i}$ の累積值 $\sum \theta_{i}$ を降伏変形 $\theta_{p}$ で除した值であり、 単位塑性仕事 $\left(M_{p} \cdot \theta_{p}\right)$ の何倍のエネルギーを吸収したかを表す指標 である。一般的な鋼部材の復元力特性は完全弾塑性型とはならない が、エネルギー吸収量が等価な完全弾塑性型に換算する。即ち、履 歴吸収エネルギーを単位塑性仕事で除した

$$
{ }_{M} \bar{\eta}={ }_{M} W_{p} /\left(M_{p} \cdot \theta_{p}\right)
$$

ここで、 ${ }_{M} W_{p}$ : 部材が吸収した塑性歪工ネルギー、 $M_{p}$ : 全 塑性モーメント(軸力の影響を考慮)、 $\theta_{p}$ : 全塑性モーメン

\section{トに対応する弾性変形}

を累積塑性変形倍率として扱う。本論文では、 ${ }^{\prime} \bar{\eta}$ を部材の等価累 積塑性変形倍率とよぶ。

構造物の耐震性能を評価するには、ランダムな繰り返し荷重を受 ける鋼部材が許容し得る ${ }_{n} \bar{n}$ を正しく評価する必要がある。繰り返 し荷重を受ける鋼部材が許容し得る ${ }^{2} \bar{\eta}$ の最小值は、図-2に示すよ うに、初めて到達した荷重レベルでの履歴曲線をつなぎ合わせるこ とで得られる骨格曲線が一方向荷重下での荷重-変形関係と良い対 応を示す ${ }^{3)}$ という経験則に基づき評価する。ここで、骨格曲線につ いても吸収エネルギー ${ }_{M} W_{p s}$ を単位仕事で除した等価塑性変形倍率

$$
{ }_{M} \bar{\eta}_{s}={ }_{M} W_{p s} /\left(M_{p} \cdot \theta_{p}\right)
$$

で塑性変形能力を表す。地震荷重を受ける多層骨組については、構 成部材の骨格曲線での等価塑性変形倍率 ${ }_{M} \bar{\eta}_{s}$ と㸴の累積塑性変形倍 率、そして骨組全体の耐震性能の関係式 ${ }^{4}$ が導かれており、多首骨

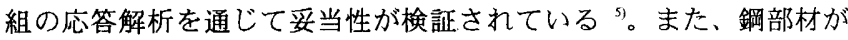

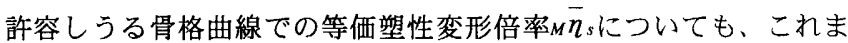
で数多く行われてきた実験を通じて、局部座屈により最大耐力が決

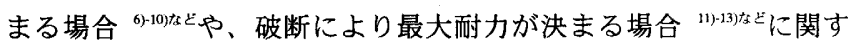
る多くの知見が得られている。
*1 東京工業大学統合研究院 助教授. 博士 (工学)

*2 東京工業大学 大学院生・修士 (工学)

*3 東京工業大学建築物理研究センター 日本学術振興会特別研究員・博士 (工学)
Assoc. Prof., Integrated Research Institute, Tokyo Institute of Technology, Dr. Eng. Graduate Student, Tokyo Institute of Technology, M. Eng.

JSPS Research Fellow, Structural Engineering Research Center, Tokyo Institute of Technology, Dr. Eng. 
一方、繰り返し荷重下における履歴曲線から抽出した骨格曲線が 一方向荷重下での挙動と良い対応を示すという経験則は、塑性域に おいて比較的大きな振幅で繰り返し載荷を受ける鋼材の応力度-歪 度関係においても成り立つことが知られている ${ }^{15,1,16}$ 。鋼部材の履歴 挙動は鋼材の応力度-歪度関係に基づくものであることから、応力 度-歪度関倸における補エネルギーと部材の塑性変形能力の対応に 着目した研究 ${ }^{17} や 、$ 部材の塑性化の程度と最大応力発生点における 歪の進展の関係に着目した研究 ${ }^{18}$ 、繰り返し荷重を受ける部材にお いて荷重-変形関係が骨格曲線上にあるときの歪の進展に着目して

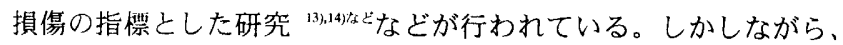
実験では局所的な歪は計測できても応力は計測できないこともあ り、地震荷重のようなランダムな繰り返し荷重下において素材レベ ルでの損傷と鋼部材の損傷とがどの様に対応しているかについて は、十分に明らかにされている訳ではない。

本研究では、地震荷重のようなランダムな絽り返し荷重を受ける 鋼部材の塑性変形能力を塑性化部位における歪の累積に基づき評価 する研究の第一段階として、一定軸力と繰り返し曲げを受ける鋼部 材を対象に、部材の最大耐力を決定づける䇢所における応力度-歪 度関係での骨格曲線と部材の荷重-変形関係での骨格曲線での損傷 の関倸を、数值解析により検討する。

\section{2.鋼部材ならびに鋼材における損甥の表現}

本研究では、図-3に示す一定軸力と繰り返し曲げを受ける片持梁 形式の鋼部材(以後、本論文中では部材と表記する)を対象とし、部 材の損傷を等価累積塑性変形倍率 $M \bar{n}$ 之骨格曲線における等価塑性 変形倍率 ${ }_{M} \bar{\eta}_{s}$ で表す。同様に鋼材(以後、本論文中では素材と表記す る)についても、応力度-歪度関係における等価累積塑性歪倍率を

${ }_{m} \bar{\eta}={ }_{m} W_{p} /\left(\sigma_{y} \cdot \varepsilon_{y}\right)$

ここで、 ${ }_{m} W_{p}:$ 公称応力度-公称歪度関係において吸収した 塑性歪工ネルギー、 $\sigma_{y}$ :降伏応力度、 $\varepsilon_{y}$ :降伏歪

と定義し、骨格曲線についても等価塑性歪倍率を

${ }_{m} \bar{\eta}_{s}={ }_{m} W_{p s} /\left(\sigma_{y} \cdot \varepsilon_{y}\right)$

ここで、 ${ }_{m} W_{p s}$ : 真応力度-真歪度関係における骨格曲線に 対応する公称応力度-公称歪度関係において吸収した塑性 歪エネルギー

と定義し、素材レベルでの損傷を表す指標として用いる。

ここで、応力度-歪度関係における骨格曲線は、真応力度-真丕度 関係において新たに到達した応力レベルでの応力度-歪度関係をつ なぎ合わせたものである。一方、塑性歪エネルギーを公称応力度公称歪度関係において求めるのは、力と変形の積で定義されるエネ ルギーに対し、それぞれを不変量である原断面積と元長さで除した 公称応力度と公称歪度を用いるのが適切であることによる。

なお、本研究では、部材の最大耐力を支配する箇所の歪として、

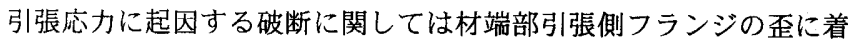
目する。圧縮㐫力に起因する局部座屈については、最大耐力規定点 9,10) となる点、すなわち $\mathrm{H}$ 形断面梁部材は固定端からフランジ幅の 半分離れた位置 ${ }^{100} の 、$ 箱形断面柱部材では固定端からフランジ幅の 0.4 倍離れた位置 "の圧縮側フランジの歪に着目する。

\section{3. 部材の面内解析方法}

繰り返し曲げを受ける部材の解析は、数值積分による面内解析方 法9)泉により行う。解析の前提条件を以下に示す。

(1)変形前に材軸に直交していた断面においては、変形後におい ても断面内の曲率は均一、即ち平面を保つものとする。

(2)材料の非圧縮性および真応度力-真歪度関係における引張と 圧縮での対称性を仮定する。

(3)断面内各点における素材の応力度-歪度関係(真応力度-真歪度 関係)には、文献 19)の履歴モデルを用いる。

(4)せん断に対しては常に弾性を仮定する。また、せん断変形と 曲げ変形は互いに影響しあわないものとする。

(5)断面の残留応力は無視する。

以上の条件の下でまず断面を図-4(1)のように分割し、断面内の力 の釣り合いを解くことでモーメント-曲率関係を求める。次いで部 材を図-4(2)のように分割し、各微小区間で一定と仮定した曲率を 材軸方向に積分することで、部材の変形を求める。

本解析は素材の簡潔な履歴モデルを用いたものであるが、載荷履 歴をパラメーターとした $\mathrm{H}$ 形断面梁部材の繰り返し曲げ実験結果 を追跡したところ、荷重-変形関係だけでなく、骨格曲線の変形量 や履歴吸収エネルギー量の推移、材端部の断面におけるモーメント 一曲率関倸や歪の履歴といった局所的な挙動に至るまで良好な対応 を示した ${ }^{199}$ 。本研究における解析的検討に十分有効であると考える。 また、本解析で用いる文献 19)の履歴モデルは真応力度-真歪度関係 をモデル化したものであることから、このモデルを用いることで体 積変化に伴う圧縮側と引張側での非対称性も考慮することになる。

\section{4. 梁部材における部材と素材の骨格曲楾における損偒の対応}

\section{1 解析パラメーター}

解析パラメーターは、部材の形状(断面成と材長)、使用素材およ び載荷パターンとする。パラメーターの一覧を表-1に、繰り返し載 荷のパターンを図-5に示す。使用素材については一般的な構造用鋼 材である SS400 材と SM490A 材について图-6に示す 3 種類を設定 し、フランジとウェブは同一とする。このうち、SS400 (1)材と SM490A 材はそれぞれ文献 19),20)で用いたものであり、本研究で 用いる履歴モデルの適用性は確認済である。また、両素材は降伏比 が $60 \%$ 程度であったため、降伏比が $72 \%$ と高めの SS400 (2)材につ いても検討を行った。一方載荷パターンについては部材実験におけ る載荷履歴として一般的に用いられている同一振幅で 1 回もしくは 2 回の繰り返しを行う漸増変位振幅(パターン 1 とパターン 2 )に加 え、地震荷重下ではランダムな履歴を受けることから、規則性の無 い俧意的な載荷履歴を与えた場合(パターン 3 )についても検討を行 った。

\section{2 一方向荷重を受ける場合の部材と素材の損甥の対応}

部材の損傷と素材の損傷の基本的な対応関係を調べるため、繰り 返し荷重下における検討に先立ち、一方向荷重を受ける梁部材の解 析結果について検討を行った。荷重-変形関係から得られた等価塑 性変形倍率 $M \bar{\eta}_{s}$ と、破断ならびに局部座屈に着目した点での等価塑

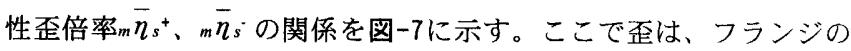
板厚方向の平均値を用いた。 
一方向荷重を受ける梁部材において、部材の等洒塑性変形倍率 ${ }_{M} \vec{\eta}_{s}$ と破断ならびに局部座屈に着目した点での等価塑性歪倍率 $m \bar{\eta}_{s}{ }^{+}$、 ${ }_{m} \bar{\eta}_{s}$ の関係はほぼ線形である。この関係は、断面成の影響はほとん ど受けないが、材長については、最も短い $2000 \mathrm{~mm}$ のモテルにお いて部材の等価塑性変形倍率 ${ }_{M} \bar{\eta}_{s} に$ 対する破断に着目した点での等 価塑性歪倍率 $m \bar{\eta}^{+}{ }^{+}$が他のモデルより $10 \%$ 以上大きくなっている。こ れは、材長が短い部材では弾性を仮定したせん断変形の占める割合 が大きいことによる。また素材の違いの影響であるが、部材の等伍 塑性変形倍率 $M \bar{\eta}_{s}$ が比較的小さな領域では降伏棚の短い SM490A 材 では破断に着目した点での等価塑性歪倍率 $\bar{n} \bar{n}^{+}$が他のモデルより小 さくなっており、 ${ }^{n} \bar{\eta}_{s}$ が比較的大きな領域では、降伏比の高い SS400 (2)材で破断に着目した点での等価塑性歪倍率 ${ }_{m} \bar{\eta}_{s}{ }^{+}$が他のモデルより 大きくなっている。塑性変形の小さな領域では降伏棚が長いほど、 塑性変形の大きな領域では降伏比が高いほど、材端部における損傷 レベルが高くなりやすいことがわかる。なお、最大応力点となる材 端部からフランジの半幅分離れている局部座届に着目した点での等 洒塑性歪倍率 $m \bar{n}_{s}$ には、材長や素材の違いによる影響は顕著に表れ なかった。

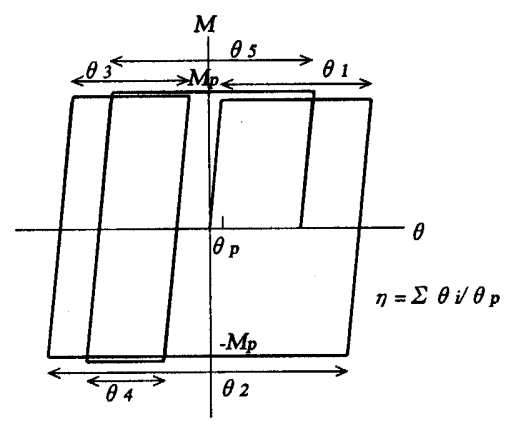

図-1 累積塑性変形倍率

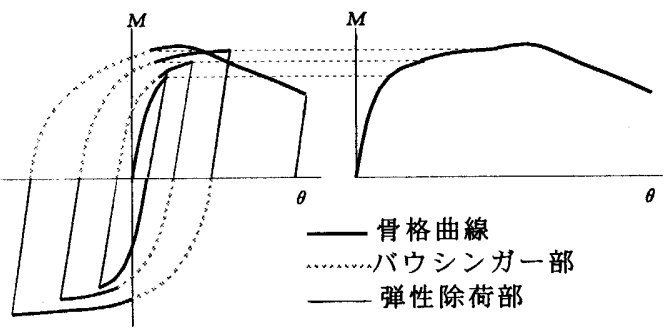

図-2 骨格曲線

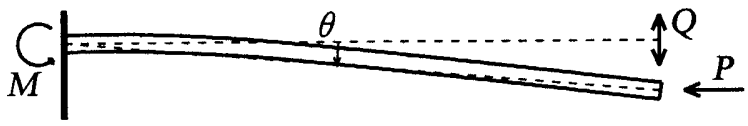

図-3 解析対象(片持ち梁モデル)

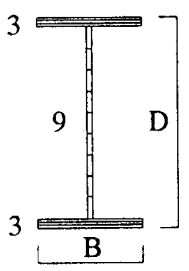

(1)断面の分割

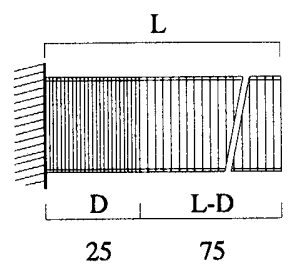

(2)材軸方向の分割
図-4 断面および材軸方向の分割
表-1 梁部材の解析パラメーター

\begin{tabular}{|c|c|c|c|}
\hline 霅材 & 断面 & $\begin{array}{c}\text { 部材長 } \\
\text { (mm) }\end{array}$ & 載荷パターン \\
\hline $55400(1)$ & $H-400 \times 300 \times 12 \times 20$ & 2000 & 一方向 \\
\hline$S \$ 400(2)$ & $H-600 \times 300 \times 12 \times 20$ & 4000 & 繰り返しパターン1 \\
\hline SM490A & $\mathrm{H}-800 \times 300 \times 12 \times 20$ & 6000 & $\begin{array}{l}\text { 緥り返しパターン2 } \\
\text { 綝り返しパターン3 } \\
\end{array}$ \\
\hline 3 & 3 & 3 & $x 4=108$ 通り \\
\hline
\end{tabular}

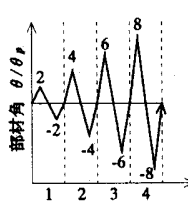

縞り返し数

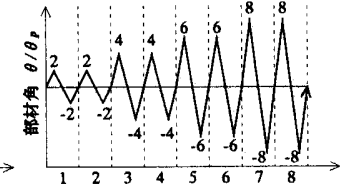

綀り返し数

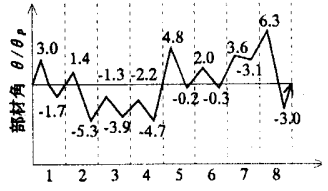

菓り返し
(1)パターン 1

(2)パターン 2

(3)パターン 3

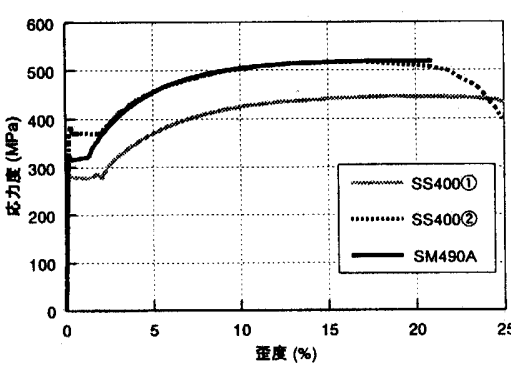

図-6 解析に用いた素材の材料特性
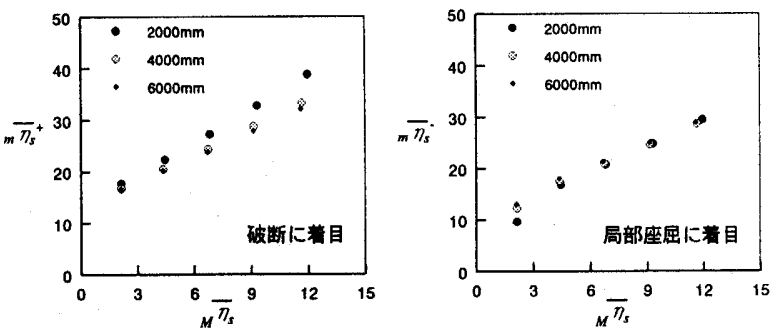

(1) 材長の違いによる比較(SS400 (1)材、断面成 $600 \mathrm{~mm}$ )
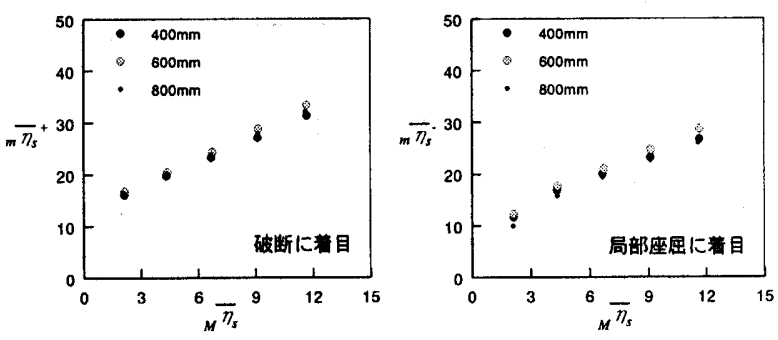

(2) 断面成の逢いによる比較(SS400 (1)材、材長 $4000 \mathrm{~mm}$ )
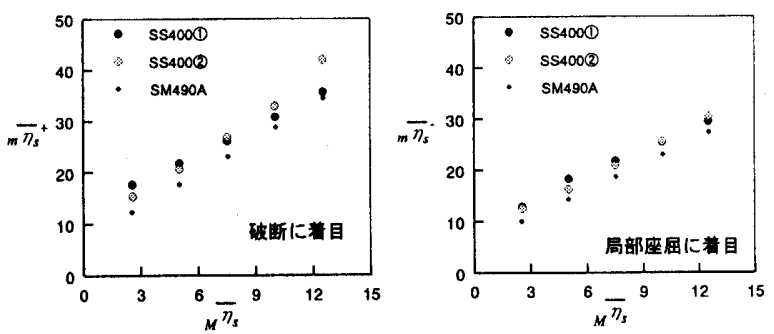

(3) 素材の違いによる比較(梁成 $600 \mathrm{~mm}$ 、材長 $4000 \mathrm{~mm}$ ) 図-7 一方向荷重下における $\bar{\eta}_{s}$ と $m \bar{\eta}_{s}{ }^{+} 、 m \bar{\eta}_{s}$ の関係 

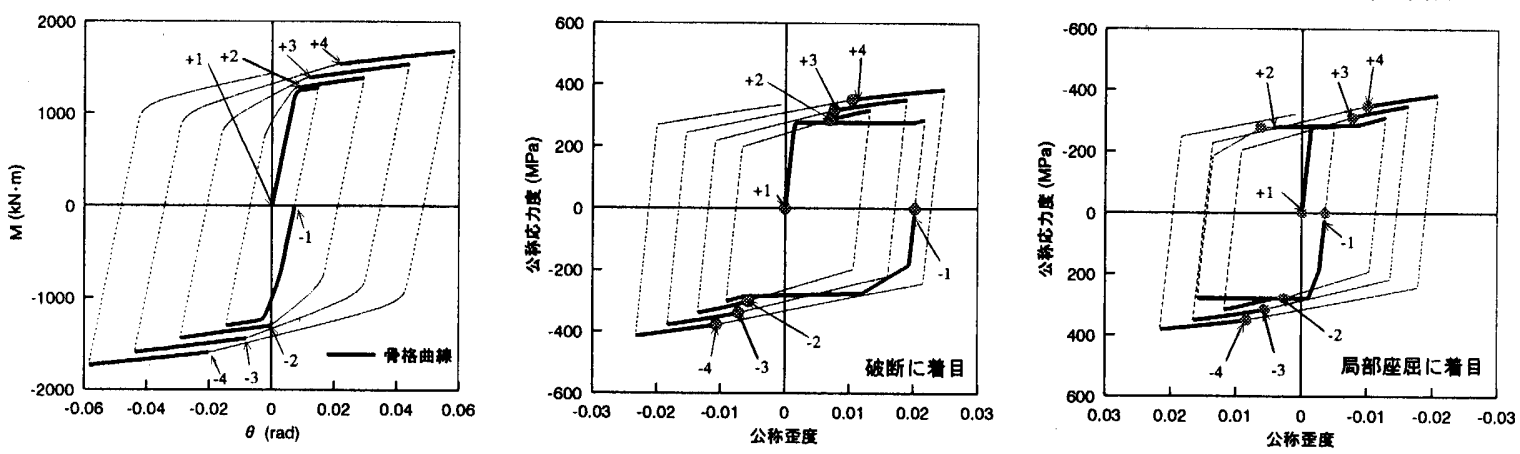

(1)繰り返しパターン 1 とした場合

— 部材の骨格曲線に対応する部分 素材の骨格曲線の開始点
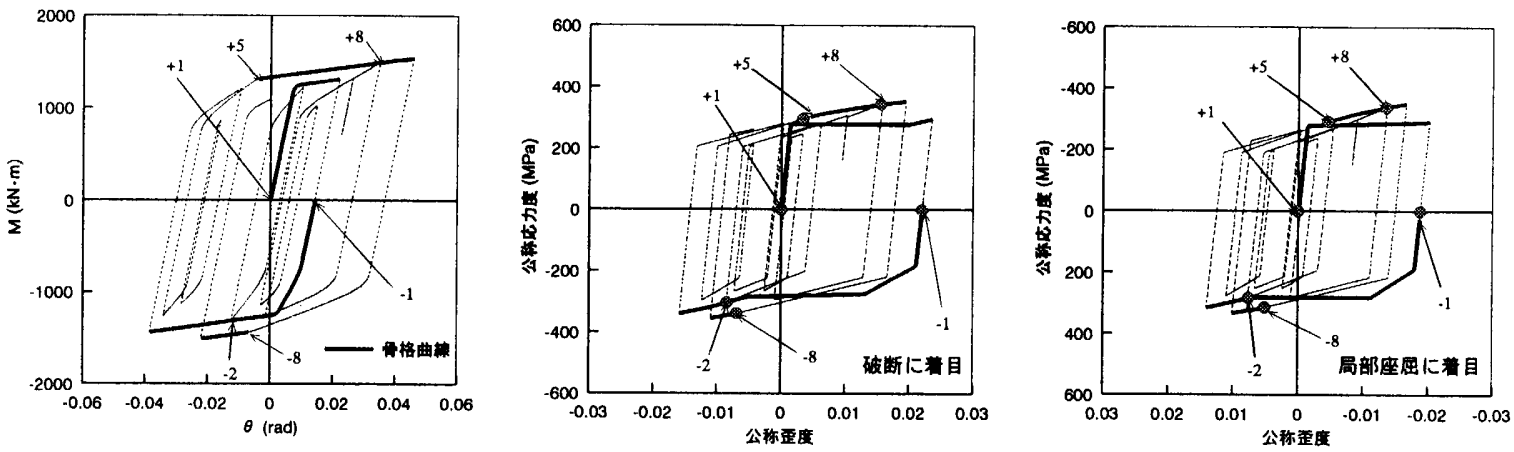

(2)繰り返しパターン 3 とした場合

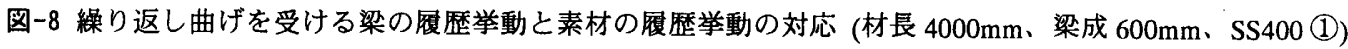

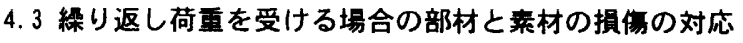

まず部材の履歴举動と、部材中における素材レベルでの履歷挙動 の対応について検討する。解析より得られた部材の荷重-変形関係 を、材長 $4000 \mathrm{~mm}$ 梁成 $600 \mathrm{~mm}$ で素材を SS400 (1)としたモデルで代 表し、綝り返しパターン 1 の場合を图-8(1)に、絽り返しパターン 3 の場合を図-8(2)に示す。併せて、破断および局部座屈に着目した 点での公称応力度-公称歪度関係も示す。なお、部材之素材の履厤 の対応を見やすくするため、局部座屈に着目した点では軸を反転し て示している。また、部材の荷重-変形関係おいて骨格曲線上にあ るときを荷重-変形関係、公称応力度-公称歪度関係において太線で 表し、素材の真応力度-真歪度関係において骨格曲線の開始点とな る点を公称応力度-公称歪度関係上に でプロットする。図中の $+\mathrm{N},-\mathrm{N}(\mathrm{N}$ は整数)は、部材の履歴において $\mathrm{N}$ 回目の正側もしくは負 側の荷重領域における履歷曲線での、骨格曲線の開始点と対応する 点であることを表す。载荷履歴によらず、荷重-変形関係における 骨格曲線の開始点と、部材中における素材レベルでの骨格曲線の開 始点は概极対応している。繰り返し荷重を受ける梁部材において、 荷重-変形関係が骨格曲線となるときには、素材の応力度-歪度関係 においてもほほ骨格曲線となることがわかった。

絑り返し荷重を受ける梁部材の荷重-変形関保から求めた正側の 等価塑性変形倍率 $\bar{n}{ }^{+}$と、破断ならびに局部座届に着目した点での 応力度-歪度関係から求めた骨格曲線における等価塑性歪倍率 $m \vec{\eta}^{*}$ 、 ${ }_{m} \bar{\eta}_{5}$ のの関係を、材長 $4000 \mathrm{~mm}$ 梁成 $600 \mathrm{~mm}$ としたモデルで代表し图9に示す。図中には一方向荷重下での $M \bar{\eta}_{s}{ }_{m} \bar{\eta}_{s^{+}} 、{ }_{m} \bar{n}_{s}$ の関係を破線
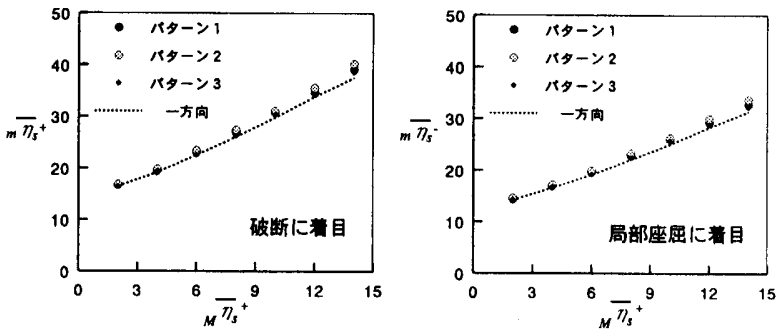

(1) SS400 (1)材の場合(材長 $4000 \mathrm{~mm}$ 、梁成 $600 \mathrm{~mm}$ )
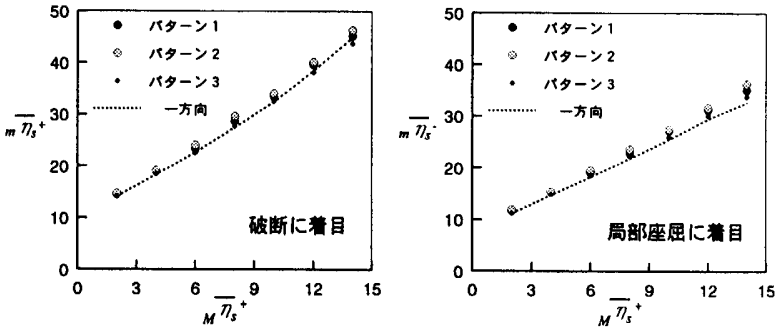

(2) SS400 (2)材の場合(材長 $4000 \mathrm{~mm}$ 、梁成 $600 \mathrm{~mm}$ )
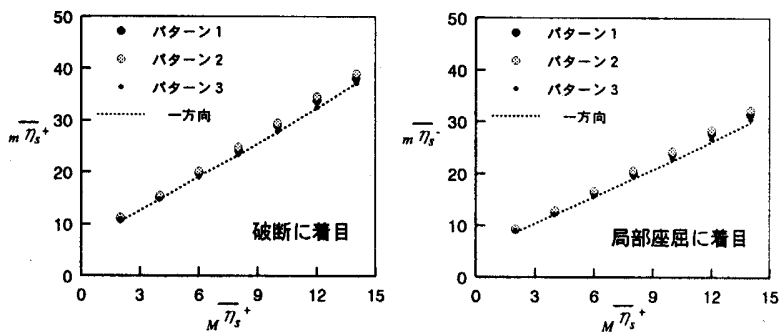

(3) SM490A 材の場合(材長 $4000 \mathrm{~mm}$ 、梁成 $600 \mathrm{~mm}$ )

図-9 絽り返し荷重下における ${ }_{M} \bar{\eta}_{s^{+}}$と ${ }_{m} \bar{\eta}_{s^{+}} 、{ }_{m} \bar{\eta}_{s}$ の関倸 
で示す。骨格曲線の等価塑性変形倍率で表した部材の損傷と骨格曲 線の等価歪倍率で表した素材の損傷の関係は、着目した位置、鋼種、 繰り返し載荷のパターンによらず、一方向荷重下における部材と素 材の損傷の関係とよく対応している。この関係は、負側の骨格曲線 についても同様であった。従って、繰り返しに伴う骨格曲線の縮小 ${ }^{21)}$ が問題にならない範囲において、繰り返し荷重を受ける梁部材の骨 格曲線が、最大耐力点も含め一方向荷重下の荷重-変形関係と対応 するという経験則を裏付ける結果と言える。

\section{5. 柱部材における部材と素材の骨格曲線における損傷の対応}

5.1 解析パラメーター

部材と素材の損傷の対応における軸力の影響を検討するため、一 定軸力とせん断曲げを受ける柱部材の解析を行った。解析対象とす る部材の断面は口-500x500×25 とし、解析パラメーターは表-2に示 す素材、部材長、軸力比 $\left(=P / P_{y}\right)$ 、載荷パターンとした。解析パラ メーターのうち、鋏種と載荷パターンは梁部材と同じである。

\section{2 一方向荷重を受ける場合の部材と素材の損偡の対応}

柱部材についても部材の損傷と素材の損傷の基本的な対応関係を 調べるため、まず一方向荷重下における検討を行った。荷重-変形 関係から得られた等価塑性変形倍率 $M \bar{\eta}_{s}$ と、破断ならびに局部座屈 に着目した点での等価塑性歪倍率 ${ }_{m} \bar{\eta}_{s^{+}} 、{ }_{m} \bar{\eta}_{s}$ の関係を図-10に示す。

一方向荷重を受ける柱部材においても、梁部材同様部材の等価塑 性変形倍率 ${ }_{M} \bar{\eta}_{s}$ と破断ならびに局部座届に着目した点での等価塑性 歪倍率 ${ }_{m} \bar{\eta}_{s}{ }^{+} 、 m \bar{\eta}_{s}$ の関係はほぼ線形となったが、軸力が作用しても 等価塑性歪倍率の分母 $\left(\varepsilon_{y}\right)$ は変化しないのに対し等価塑性変形倍率 の分母 $\left(\theta_{p}\right)$ は軸力に応じて変化することから、軸力比ごとに異なる 勾配となっている。また、せん断変形の影響により材長が短いほど 材端部にある破断に着目した点での等価塑性歪倍率 ${ }_{m} \bar{\eta}_{s}{ }^{+}$は大きめの 值となったが、材端から一定の距離にある局部座屈に着目した点で の等価塑性歪倍率 $m \bar{n}_{s}:$ には、せん断変形の影響よりも态力勾配の影 響が顕著に現れ、材長が長いほど大きめの值となった。そして素材 の違いの影響であるが、梁部材ではほとんど違いの見られなかった 局部座屈に着目した点において、压縮軸力下では塑性変形の小さな 領域で降伏棚が長いほど損傷レベルが高くなる傾向が見られた。一 方、梁部材で素材の違いの影響が見られた破断に着目した点では、 引張軸力下では同様に素材による違いが見られたが、圧縮軸力下で はほとんど違いは見られなかった。これは、軸力の影響により圧縮 軸力下では圧縮側の、引張軸力下では引張側の塑性歪がより大きく 進展し、比較的塑性変形の小さな領域で歪硬化域に達したことで、 応力度-歪度関係の違いが顕著に現れたものである。素材の降伏棚 が長いほど、また降伏比が高いほど、歪硬化による塑性域の広がり が抑制されることから、等価塑性歪倍率で表される局所的な損傷レ ベルは高くなる。

\section{3 繰り返し荷重を受ける場合の部材と素材の損賃の対応}

部材の履歴挙動と、部材中における素材レベルでの履歴举動の対 応について検討する。解析より得られた部材の荷重-変形関係を材 長 $1600 \mathrm{~mm}$ で素材を SS400 (1)としたモデルで代表し、軸力比+0.4(引 張軸力)で繰り返しパターン 1 とした場合を図-11(1)に、軸力比-0.2 (圧縮軸力)で繰り返しパターン 3 とした場合を図-11(2)に、軸力比
表-2 柱部材の解析パラメーター

\begin{tabular}{|c|c|c|c|c|}
\hline 鎆材 & $\begin{array}{c}\text { 部材 長 } \\
(\mathrm{mm})\end{array}$ & 軸力比:1 & 載荷パターン*2 & \\
\hline & 1200 & 0.0 & 一方向 & *1:十は引張軸力を表す \\
\hline SS400(1) & 1600 & $+0.2-0.2$ & 緤り返しパターン1 & \\
\hline$s S 400(2)$ & 2000 & $+0.4-0.4$ & 繰り返しパターン2 & *2:載荷パターンにつ \\
\hline SM490A & 2400 & $\begin{array}{r}+0.6-0.6 \\
+0.8-0.8 \\
\end{array}$ & 樏り返しパターン3 & いては梁部材と同じ \\
\hline 3 & 4 & $9 \times$ & $\times 4=432$ 通り & \\
\hline
\end{tabular}
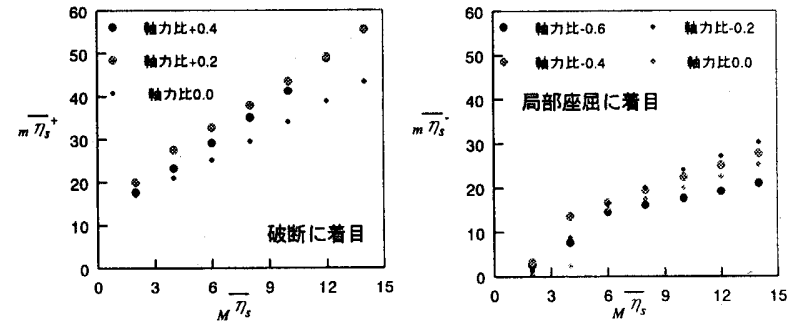

(1) 軸力比の違いによる比較(SS400 (1)材、材長 $1600 \mathrm{~mm}$ )
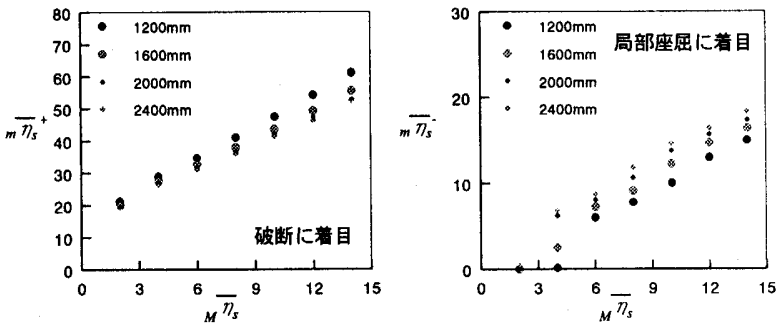

(2) 材長の違いによる比較(SS400 1)材、軸力比 +0.2 引張)
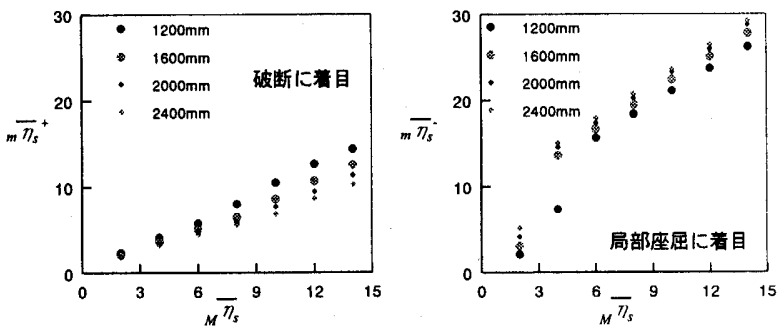

(3) 材長の違いによる比較(SS400 (1)材、軸力比-0.4_圧縮)
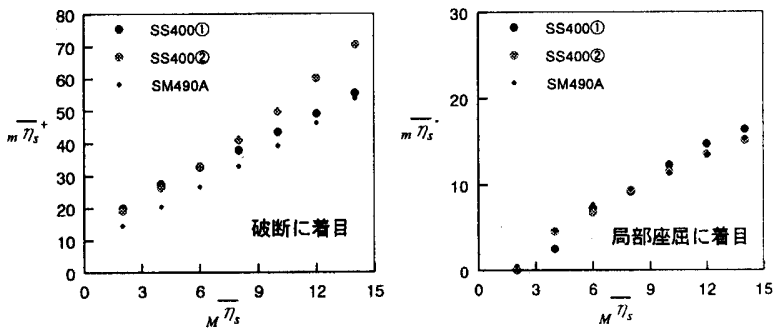

(4) 素材の違いによる比較(材長 $1600 \mathrm{~mm}$ 、軸力比+0.2_引張)
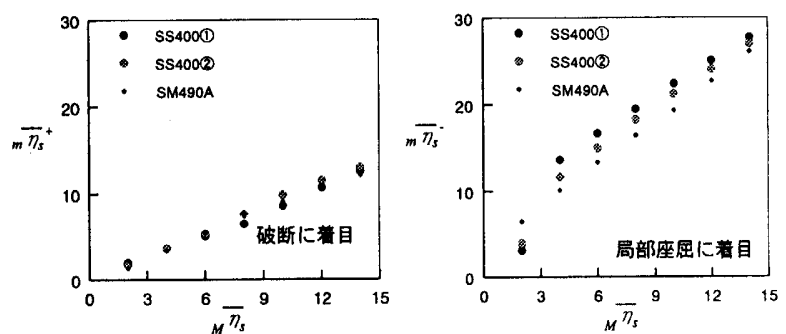

(5) 素材の違いによる比較(材長 $1600 \mathrm{~mm}$ 、軸力比-0.4_圧縮)

図-10 一方向荷重下における $\bar{\eta}_{s} \bar{n}_{m} \bar{\eta}_{s^{+}} 、 m \bar{\eta}_{s}$ の関係 

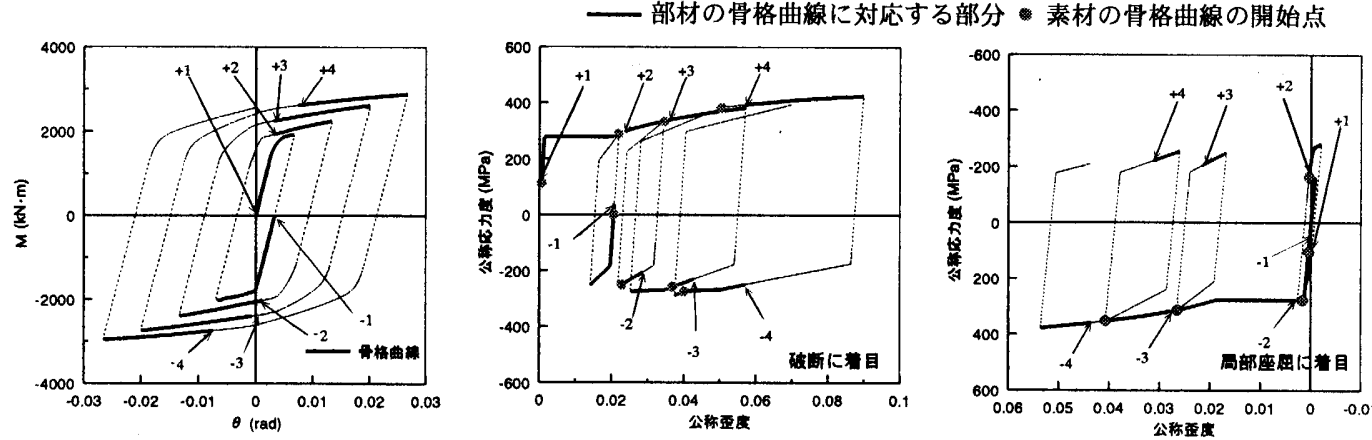

(1)軸力比+0.4(引張軸力)のもとで繰り返しパターン 1 とした場合

—— 部材の骨格曲線に対応する部分 ・素材の骨格曲線の開始点
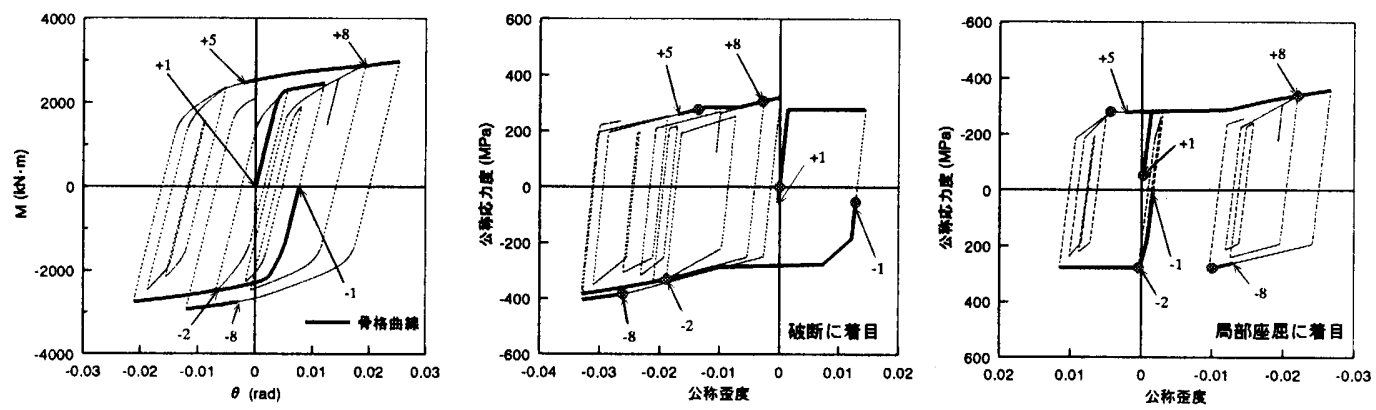

(2)軸力比-0.2(圧縮軸力)のもとで絽り返しパターン 3 とした場合

一一 部材の骨格曲線に対応する部分・素材の骨格曲線の開始点
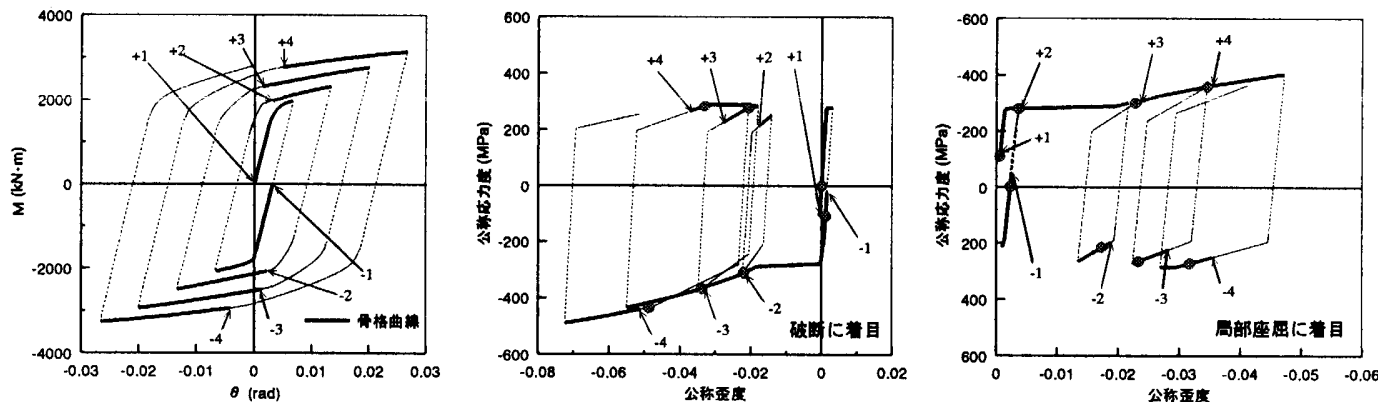

(3)軸力比-0.4(圧縮軸力)のもとで繰り返しパターン 1 とした場合

図-11 繰り返し曲げを受ける柱の履歴挙動と素材の履歴挙動の対応 (材長 $1600 \mathrm{~mm} 、 S S 400$ (1)

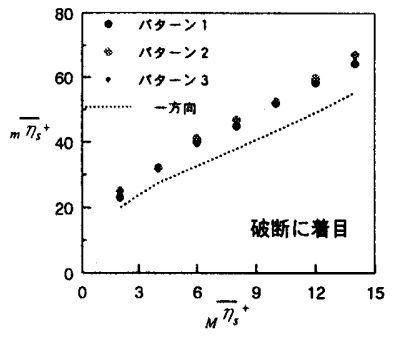

(1) 軸力比 +0.2 (引張)

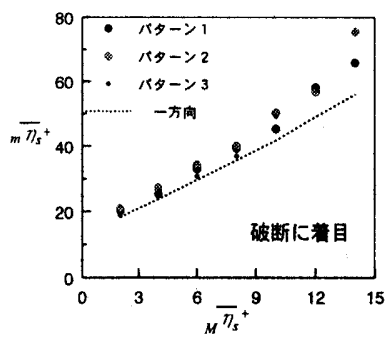

(2) 軸力比+0.4(引張)
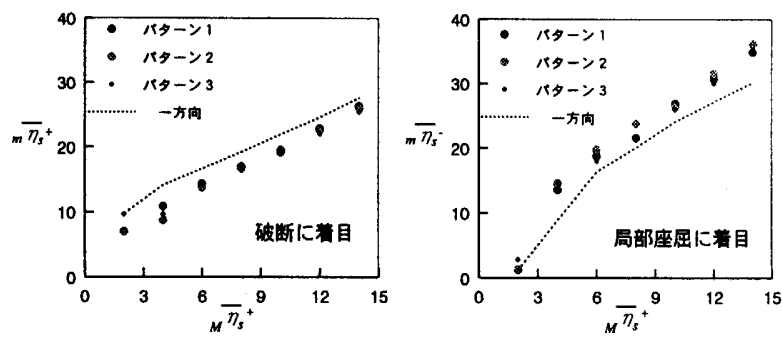

(3) 軸力比- 0.2 (圧縮)
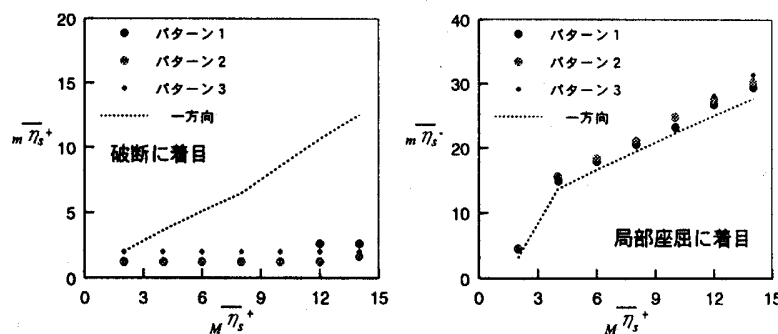

(4) 軸力比- 0.4 (圧縮)

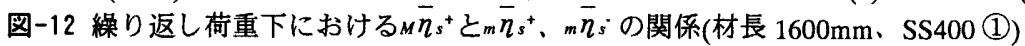


-0.4 (圧縮軸力)で繰り返しパターン 1 とした場合を図-11(3)に示す。 併せて、破断および局部座屈に着目した点での公称応力度-公称歪 度関係も示す。なお部材と素材の履歴の対応を見やすくするため、 局部座屈に着目した点では軸を反転して示している。また、部材の 荷重-変形関倸おいて骨格曲線上にあるときを荷重-変形関係、公称 応力度-公称歪度関係において太線で表し、素材の真応力度-真歪度 関係において骨格曲線の開始点となる点を公称応力度-公称歪度関 係上にでプロットする。図中の+N,-N(N は整数)は、部材の履歴 において $\mathrm{N}$ 回目の正側もしくは負側の荷重領域における履歴曲線 での、骨格曲線の開始点と対応する点であることを表す。

軸力比の小さい(土 0.2)部材では、梁部材同様荷重-変形関係にお ける骨格曲線の開始点と、部材中における素材レベルでの骨格曲線 の開始点は概数対応している。一方、軸力比が大きくなると、破断 に着目した点と局部座屈に着目した点のいずれにおいても、圧縮軸 力が作用する場合には圧縮側において、引張軸力が作用するときに は引張側において、荷重-変形関係における骨格曲線の開始点と、 部材中における素材レベルでの骨格曲線の開始点は概ね対応する が、圧縮軸力が作用する場合の引張側、引張軸力が作用するときの 圧縮側では、荷重-変形関係における骨格曲線の開始点と部材中に おける素材レベルでの骨格曲線の開始点の対応は悪くなる。この傾 向は軸力比が大きくなるほど顕著になっている。

また、繰り返し荷重を受ける柱部材の荷重-変形関係から求めた 正側の等価塑性変形倍率 $M \vec{n} \vec{s}^{+}$と、破断ならびに局部座屈に着目した
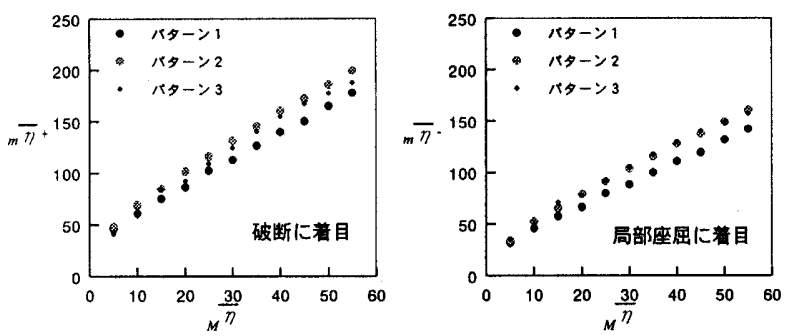

(1) SS400 (1)材の場合
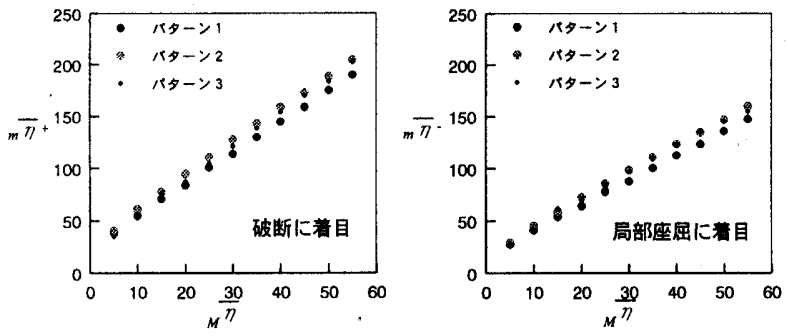

(2) SS400 (2)材の場合
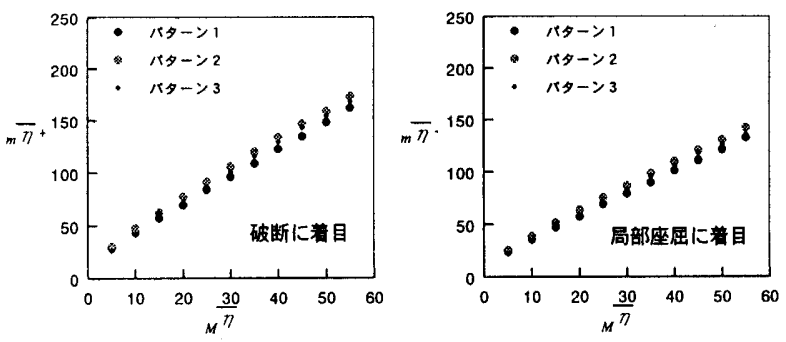

(3) SM490A 材の場合

图-13 繰り返し荷重を受ける梁の $\bar{\eta}_{\bar{\eta}}{ }_{m} \bar{\eta}^{+} 、{ }_{m} \bar{\eta} \cdot$ の関係 (材長 $4000 \mathrm{~mm}$ 梁成 $600 \mathrm{~mm}$ )
点での応力度-歪度関係から求めた骨格曲線における等価塑性歪倍

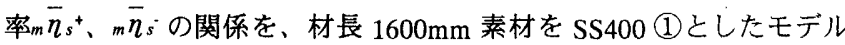
で代表し図-12に示す。図中には一方向荷重下での ${ }_{M} \bar{\eta}_{s}{ }_{m} \bar{\eta}_{s}{ }^{+} 、{ }_{m} \bar{\eta}_{s}$ の関係を破線で示す。引張軸力下において破断に着目した点での等 価塑性丕倍率 $m \bar{\eta}_{s}{ }^{+}$、圧縮軸力下において局部座屈に着目した点での 等価塑性丕倍率 $m \bar{\eta}_{s}$ 之部材の骨格曲線での損傷との関係は、梁部材 同様一方向荷重下における関係と概ね対応している。この関係は、 負側の骨格曲線についても同様であった。一方、圧縮軸力下におい て破断に着目した点での等価塑性歪倍率 $m \bar{n}^{+}$、引張軸力下において 局部座屈に着目した点での等価塑性歪倍率 $\bar{\eta}_{i} \bar{\eta}^{\prime}$ 之部材の骨格曲線で の損傷との関係は、軸力比が大きくなるほど対応が悪くなった。し かしながら、一般に破断が問題となるのは圧縮軸力がほとんど作用 しないような条件下であり、局部座屈が問題となるのは圧縮軸力下 である。繰り返し荷重を受ける部材の骨格曲線が、最大耐力点も含 め一方向荷重下の荷重-変形関係と対応するという経験則は、繰り 返しに伴う骨格曲線の縮小 ${ }^{21}$ が問題にならない篹囲において、一般 的な柱部材においても裏付けられたと言える。

\section{6. 結り返し荷重を受ける部材と素材の累積損賃の対応}

綠り返し荷重を受ける部材の全履歴における損傷と、素材レベル での損傷の対応を検討する。まず、繰り返し曲げを受ける梁部材の 荷重-変形関係から得られた等価累積塑性変形倍率 ${ }_{M} \bar{\eta}$ 之、破断なら
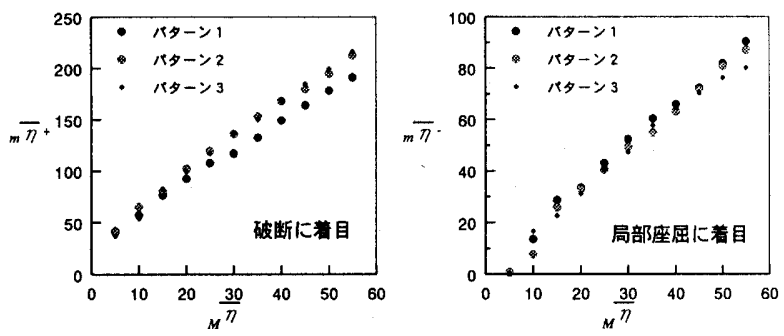

(1) 軸力比 +0.2 (引張)の場合
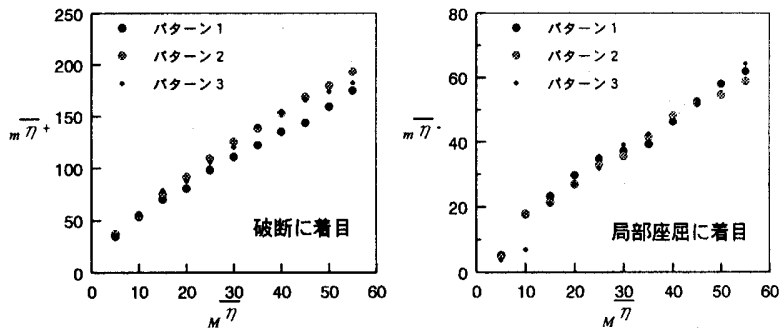

(2) 軸力比-0.2(圧縮)の場合
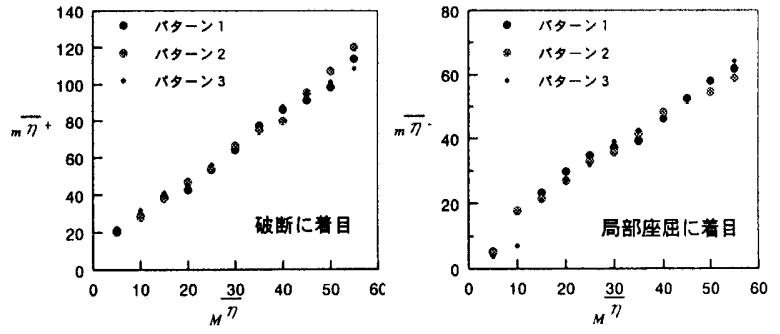

(3) 軸力比-0.4(厌縮)の場合

图-14 繰り返し荷重を受ける梁の $\bar{n}_{\bar{\eta}} \varepsilon_{m} \bar{\eta}^{+} 、{ }_{m} \bar{\eta} \cdot$ の関係 (材長 $1600 \mathrm{~mm} 、 S S 400$ (1) 
びに局部座屈に着目した点での等価累積塑性丕倍率 $m \bar{\eta}^{+} 、 m \bar{n}$ の関 係を、材長 $4000 \mathrm{~mm}$ 梁成 $600 \mathrm{~mm}$ としたモデルで代表し図-13に示 す。継り返し載荷のパターンによらず、等価累積塑性変形倍率と等 価累積塑性歪倍率の間には、ほぼ一本の直線で表せる関係が見られ る。次に、一定軸力下で繰り返し曲げを受ける柱部材の荷重-変形 関係から得られた等価累積塑性変形倍率 $M \vec{\eta}$ と、破断ならびに局部 座屈に着目した点での等価累積塑性歪倍率 $\bar{n}^{+}+{ }_{m} \bar{n}$ の関係を、材 長 $1600 \mathrm{~mm}$ 素材を SS400 (1)としたモデルで代表し図-14に示す。柱 部材の場合も、軸力比や繰り返し載荷のパターンによらず、等価累 積塑性変形倍率々等価累積塑性歪倍率の間には、ほほ一本の直線で 表せる関係が見られる。部材レベルならびに素材レベルでの損傷の 指標として骨格曲線および全履歷での等価累積塑性変形倍率と等価 累積塑性歪倍率を用いることで、骨格曲線の縮小 ${ }^{21}$ のような繰り返 しの効果を含め、部材の損傷が素材レベルの損傷と統一的に評価で きることを示している。

\section{7. 結論}

一定軸力下でランダムな継り返し曲げを受ける部材を対象に、荷 重-変形関係での履歴吸収エネルギーで表される部材の損傷と素材 レベルでの損傷の関係を、数值解析により検討した。素材レベルで の損傷を代表する部材の最大耐力を支配する籄所の歪としては、破 断に関しては材端部引張側フランジの歪に、局部座屈に関しては最 大耐力規定点 ${ }^{9,10}$ となる点、すなわち $\mathrm{H}$ 形断面梁部材は固定端から フランジ幅の半分離れた位置 ${ }^{10}$ の、箱形断面柱部材では固定端から フランジ幅の 0.4 倍離れた位直 の圧縮側フランジの歪にそれぞれ 着目した。本研究で得られた結論を以下にまとめる。

1)繰り返し曲げを受ける梁部材では、部材の荷重-変形関係が骨格 曲線となるときには素材の応力度-歪度関係においてもほぼ骨格曲 線となる。

2)一定軸力と繰り返し曲げを受ける柱部材の場合、軸力比が小さい (土0.2)場合には、部材の荷重-変形関係が骨格曲線となるときには 素材の応力度-歪度関係においてもほぼ骨格曲線となる。軸力比が 大きくなると、圧縮軸力が作用する場合の圧縮側、引張軸力が作用 するときの引張側では、荷重-変形関係における骨格曲線と素材の 骨格曲線は概权対応するが、圧縮軸力が作用する場合の引張側、引 張軸力が作用するときの王縮側では両者の対応は悪くなる。 3)紹り返し曲げを受ける梁部材の損傷を荷重-変形関係から抽出し た骨格曲線の等価塑性変形倍率で表し、素材の損傷を着目した箇所 での応力度-歪度関係から抽出した骨格曲線の等価塑性歪倍率で表 すと、両者の関係は着目した位置、鋼種、繰り返し載荷のパターン に関わらず、一方向荷重下における関係と良い対応を示す。これは、 繰り返しに伴う骨格曲線の縮小 ${ }^{2 \mathrm{n}}$ が問題にならない範囲において、 繰り返し荷重を受ける梁部材の骨格曲線が、最大耐力点も含め一方 向荷重下の荷重-変形関係と対応するという経験則を裹付ける結果 と言える。

4)繰り返し荷重を受ける柱部材の損傷を荷重-変形関係から抽出し た骨格曲線の等価塑性変形倍率で表し、素材の損傷を着目した箇所 での応力度-歪度関倸から抽出した骨格曲線の等価塑性歪倍率で表 すと、引張軸力下における部材の等価塑性変形倍率と引張側の等価
塑性丕倍率の関倸と、圧縮軸力下における部材の等価塑性変形倍率 と压縮側の等価塑性歪倍率の関係は、梁部材同様一方向荷重下にお ける関係と概ね対応した。一般に破断が問題となるのは圧縮軸力が ほとんど作用しないような条件下であり、局部座屈が問題となるの は圧縮軸力下であることから、繰り返し荷重を受ける部材の骨格曲 線が、最大耐力点も含め一方向荷重下の荷重-変形関係と対応する という経験則は、結り返しに伴う骨格曲線の縮小 ${ }^{21}$ が問題にならな い範囲において、一般的な柱部材においても毫付けられたと言える。 5)繰り返し荷重を受ける部材の荷重-変形関係から得られた等価累 積塑性変形倍率と、破断ならびに局部座屈に着目した点での等価累 積塑性歪倍率の関係は、作用軸力、繰り返し載荷のパターンによら ず、ほぼ一本の直線で表せる関係が見られた。部材レベルならびに 素材レベルでの損傷の指標として骨格曲線および全履歴での等価累 積塑性変形倍率と等価累積塑性歪倍率を用いることで、骨格曲線の 縮小 ${ }^{21}$ のような絽り返しの効果を含め、部材の損傷が素材レベルの 損傷と統一的に評価できると考えられる。

\section{参考文献}

1)秋山 宏: 建策物の耐震極限設計 第 2 版, pp.166-167, 束京大学出版会, 1987 2)秋山宏: エネルギーの釣合に基づく建築物の耐震設計，技報堂出版，1999 3)加藤 勉, 秋山宏: 鋼棈造部材の耐力 (その4), 日本建築学会論文報告集

第 151 号, pp.15-20, 1968.9

4)日本建築学会: 建築耐震設計における保有耐力と変形性能(1990).

5)山田 哲, 秋山宏: 局部座㐿を伴う銅部材の举動に立脚した多首胃組の弾 塑性応答解析, 日本建築学会構造系論文集 第 463号, pp.125-133, 1994.9

6)加藤 勉, 秋山 宏, 带 洋一: 局部座屈を伴5H形断面部材の変形,日本建 築学会論文報告集 第 257 号, pp.49-57, 1977.7

7)鉿木敏郎，小野徹郎: 生縮と曲げを受ける鉄骨H形断面柱の塑性変形能力に 関する研究 (その 1), 日本建築学会論文報告集, 第 292 号, pp.23-29, 1980.6 8)牧野 稔, 松井千秋, 三谷 勲: $\mathrm{H}$ 形鋼柱の局部座届後の変形性状 その 4 塑性変形能力,日本建築学会論文報告集 第 290) 号, pp.45-55, 1980.4

9)山田 哲, 秋山宏, 桑村 仁: 局部座届を伴う箱形断面鋼部材の少化域を

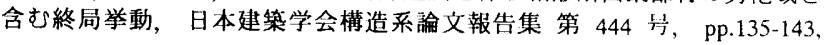
1993.2

10)山田 哲, 秋山宏, 桑村 仁: 局部座屈を伴うH形断面鍓部材の少化举動, 日本建築学会構造系論文報告集 第 454 号, pp.179-186, 1993.12

11)秋山宏, 山田 哲, 松本由香, 松岡三郎, 大竹章夫, 杉本浩一: 尖大柱梁接 合部の試験温度による延性破罗一脆性破壊遷移, 日本建築学会橉造系諭文 集第 522 号, pp.105-112, 1999.8

12)岡田 健, 呉 相勲, 山田 梊, 今枝知子, 山口路夫, 和田 章: 従来型の柱 梁接合部を有する合成梁の変形能力に関する実験的研究 合成梁の変形能 力を反映した鋼構造骨組の耐震性竍価 その1，日本建築学会榄造系論文集 第 547 号, pp.161-168, 2001.9

13)岡田 健, 呉 相 勲, 山田 梊: 合成梁の塑性変形能力に柱梁接合部にお

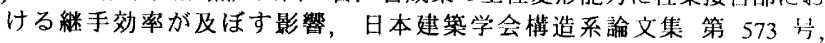
pp.185-192, 2003.11

14)吹田啓一郎，立山英二: 梁長さが巽なる溶接柱梁接合部の塑性変形能力, 鋼構造年次論文報告集, pp.601-606, 2003.11

15)加藤 勉, 青木博文, 山内泰之: 引張・圧縮絽返し荷重を受ける鋼素材の挙 動に関する実験的研究, 日本建築学会大会学術講演梗概集, pp.803-804, 1970 年 9 月。

16)加藤 勉, 秋山 宏, 山内泰之: 鋼材の応力-ひずみ履歴曲線に関する実験 則, 日本建築学会大会学術講演梗概集, pp.937-938, 1973 年 10 月

17)伊藤直幸, 小野徹郎, 吉田文久, 岩田 衛: 金属系曲げ材の変形能力と素材 特性に関する研究, 日本建築学会大会学術講演梗概集, pp.1105-1106, 1994.9 18)桑村 仁: 降伏比の異なる釦材を用いた梁-柱の面内弾塑性举動に関する解 析, 日本建築学会大会学術講演梗概集, C 分冊, pp.845-846, 1987.10

19)山田 哲, 今枝知子, 岡田 健: バウシンガー効果を考虑した構造用鋼材の 簡潔な履歴モデル，日本建築学会構造系論文集 第 559 号, pp.225-232, 2002.9

20)松本由香, 鄭 景洙, 山田 梊: 繰返し複合応力を受ける構造用鋼材の履歴 举動に関する基礎実験，日本建築学会構造系論文集 第 588 号，pp.181-188， 2005.2

21)秋山 宏, 高橋 誠, 石 軍: 繰り返し曲げを受ける师断面鋼棒の終局工 ネルギ一吸収能力，日本建築学会構造系論文集，第 475 兵， pp.145-154， 1995.9 